\title{
Investigating Rural - Urban Migration in Developing Countries of the World a Focus in Nigeria
}

\author{
Anselem Chukwuemeka Nweke \\ Department of Public Administration, Faculty of Social Science, Chukwuemeka Odumegwu Ojukwu University, Igbariam, Nigeria \\ Email address: \\ nwekeanselem@yahoo.com

\section{To cite this article:} \\ Anselem Chukwuemeka Nweke. Investigating Rural - Urban Migration in Developing Countries of the World a Focus in Nigeria. Journal of \\ Public Policy and Administration. Vol. 3, No. 3, 2019, pp. 76-81. doi: 10.11648/j.jppa.20190303.12
}

Received: September 29, 2019; Accepted: October 17, 2019; Published: November 13, 2019

\begin{abstract}
This paper investigates the reason behind rural-urban migration in developing countries of the world using Nigeria as focus of the study. The fact is that most of the countries of the developing world are just on the threshold of their industrial take-off. The unfolding of events in the western world indicates that urbanization and industrialization goes together. Thus, the simple fact that continuing rapid urbanization is inevitable in developing countries. This study examines issues of drive, implication and solution to the problem of rural-urban migration in Nigeria. In view of the emerging nature of this research work, the survey research design was used. The paper adopted urban bias theory as a model for its analytical framework. The paper observed that in Nigeria, urban centres or cities are springing up and people are migrating from the rural areas to urban areas. And they have different reasons for migrating from rural areas to urban centres; these reasons include among others lack of employment opportunities in rural areas, lack of infrastructural facilities, educational institution etc. It therefore, recommends that the government should embark on the development of agricultural sector to create employment and infrastructural development in the rural areas.
\end{abstract}

Keywords: Agriculture, Employment, Implication, Infrastructure, Rapid Development

\section{Introduction}

The obvious relationship between urbanization and industrialization is the nexus of labor attraction not only in the commercial and manufacturing activities but more importantly in agricultural production. Thus, as the conditions of opportunities expand in the urban areas, they, however, dialectically worsen in the rural areas as people are continuously attracted into the urban areas where they are dangerously forced to abandon rural life to seek a means of frivolous livelihood in the towns. Migration has also been identified as a survival strategy utilized by the poor, especially the rural dwellers [1].

Basically, in Nigeria, urban centres or cities are springing up and people are migrating from the rural areas to urban areas. And they have different reasons for migrating from rural areas to urban centres; these reasons may include among others lack of employment opportunities, lack of infrastructural facilities, educational institution etc. The deplorable condition of the Nigerian rural sector is emphatic and more worrisome is that even the few policies and programs put in place and implemented by government over the years have not resulted in significant improvement in the development of the rural areas in Nigeria. [2].

Migration is a selective process affecting individuals or families with certain economic, social, educational and demographic characteristics. The movement of people from rural to urban areas is a common occurrence in Nigeria [3]. Urban life, is generally characterized by many issues which include among others, anonymity of the individual, norm conflicts, rapid social change, increased mobility of the population and emphasize on materialism. Urban life, tends to encourage individualism and a sharp decline in intimate communication as everybody always concentrates on his or her business as a result of its heterogeneous nature [4].

The pattern, trend, and characteristics of urbanization in Nigeria have been alarming. The towns and cities have grown phenomenally with pace of urbanization in Nigeria showing extraordinary high rates of $5 \%-10 \%$ per annum [5]. Usually, urban centres assume increasing significance with the increasing rate of nation's development, for it is in these centres that a nation's capability is largely demonstrated. The 
fact is that most of the countries of the developing world are just on the threshold of their industrial take-off, and the patent deduction based on the previous unfolding of events in the western world that urbanization and industrialization goes together, indicates the simple fact that continuing rapid urbanization is inevitable in developing countries considering their level of development. As of now, the cities have been growing both through natural increase and through stampede from rural areas in Nigeria. The cause of the phenomenon has been described as the push factors in the rural areas and the pull factors in the urban centres. The dimension of the forces produced by these factors in many Nigeria communities has made "push and pull" to become understatements which could be replaced by "propulsive" and "magnetic". Honestly, the rural areas are beset by propulsive forces which send the youths in particular running post haste to the cities which have the magnetic factors that engulf the rural areas in their irresistible field [6].

It must be stressed that public policy on agriculture has by and large shown great disaffection towards the small scale farmers; particularly those on the rural areas, as the inputs, credits and other facilities concretely show its bias in favor of the large scale urban arm-chair farmers at the expense of the predominant peasant population. Thus, the improvement of the peasantry is, any way, an inevitable historical outcome the penetration of the capitalist forces into the countryside under colonial and past-colonial conditions [7]

It is imperative to note that rural pressures, essentially those centred on social infrastructural amenities; but to some extent on land especially where there exists high rural population densities and particularly where state intervention in agricultural programmes have assaulted the life of the peasantry, whose many source of livelihood are agriculture is endemic and highly colossal which however affect pressures on food supply and the threat to feed the family with an inevitable option to move out to the urban centres for the lumpen-proletarian jobs which may or may not be there. More than ever before, rural areas in Nigeria are currently confronted with serious problems ranging from the general state of underdevelopment, social backwardness to the issue of infrastructural deficiencies, impoverishment, widespread poverty and hunger, illiteracy, unemployment as well as apathy and despair.

Rural areas refer to geographical areas that lie outside the densely built-up environment of towns, cities and the suburban villages and whose inhabitants are engaged primarily in agriculture as well as the most basic of rudimentary form of secondary and tertiary activities [8]. Rural areas can be easily identified by various criteria, apart from population. Such criteria include the level of infrastructural development i.e. road networks, educational institutions, water supply, electricity, health facilities, communication, etc. [9] Other criteria used include Occupation, Housing, Extent of community planning etc. Rural area, which is the opposite of an urban area, refers to the country side whose population engages mainly in primary production activities like agriculture, fishing, and rearing of livestock [10]. About 90 percent of the rural labour workforce engages directly or indirectly in agriculture [11].

A distinguish characteristics of the city is that it is thickly populated with most of the people living in rented accommodation, while many people in the city engage in or, look for wage employment, others resort to self employment, doing various odd jobs to survive. The rural residents apparently see the attractiveness in the towns with seeming better opportunities. But in actual reality, many people abandon rural life in preference to the crowded and often substandard, squalor and shanty housing in the towns where they cannot find suitable employment opportunities [12].

Rural-urban migration is a threat to the development of the nation as its resultant effect is more on the economy of the nation than personal or individual effects. Agricultural problems, cultural problems and societal problems are some of the effects of rural-urban migration [13]. Poor electricity supply, bad condition of roads and absence of pipe-borne water in rural areas were push factors driving rural youths away from their communities into urban areas. Better employment opportunities in the cities, superior wages in the urban areas, improved living condition in the cities were found to be pull factors that attract rural youths to the urban centres [14]. The problem that stimulates this present research interest is rate at which our youths (young boys and girls) are moving from rural areas to urban centres is very alarming. This calls for deep inquiry to unravel the causes and solution to the rural-urban migration in Nigeria.

\section{Theoretical Framework}

This paper adopted urban bias theory as its framework of analysis. Among the leading scholars to claim urban bias are Michael Lipton [15] and Robert H. Bates [16]. Urban bias refers to a political economyargument according to which economic development is hampered by groups who, by their central location in urban areas, are able to pressure governments to protect their interests.

Michael Lipton's Why Poor People Stay Poor: Urban Bias in World Development. This book deals with systematic distortions of the resource allocation of less developed countries. The central idea is that the most important class conflict in the Third World is not the conflict between labour and capital or between domestic and foreign interests; it is the conflict between country and town.

Groups often said to have an 'urban bias' include governments, political parties, labor unions, students, laws, civil servants and manufacturers. These interests are portrayed as often not reflecting the comparative economic advantage of the country, usually a less-industrialized country whose comparative advantage is considered to be export agriculture.

According to Lipton, urban areas are favoured by the politicians at the expense of the countryside. This takes on a variety of forms: the infrastructure is concentrated in the cities, the countryside is taxed more harshly and the price policy turns relative prices in favour of urban pursuits. Also too many resources are spent on cities, both from the point of view of 
efficiency and from the point of view of equality. The fundamental reason why the countryside is discriminated against is political; the countryside is poor because it is politically powerless. It cannot initiate and implement policy. The consequence is that the growth of developing countries has been both slower and less equitable than it could otherwise have been. His constructive message is that as a rule you have to develop agriculture across a broad range before you start dealing with the remaining sector of the economy. It is only through the development of small-scale agriculture that per capita income can be brought to such a level that the citizens can abstain from as much consumption as is needed to start the industrialization process without inflicting pain and without having to squeeze agriculture. This is not in opposition to industrialization: the latter requires a transfer of resources from agriculture, but this is much more easily accomplished when the agricultural sector is well developed.

\section{Methodology}

Table 1. Distribution of local government on senatorial zones.

\begin{tabular}{ll}
\hline Senatorial Zones & Local Government Selected \\
\hline Anambra Central & Awka South and Awka North \\
Anambra South & Nnewi North and Orumba North \\
Anambra North & Onitsha North and Ayamelum \\
\hline
\end{tabular}

This study examines issues of drive, implication and solution to the problem of rural-urban migration in Nigeria. In view of the emerging nature of this research work, the survey research design will be used. This study will explore both the primary and secondary sources of data collection. The primary data sources shall be collected through questionnaire. A total of 1200 respondents will be selected for questionnaire administration in six (6) delineated local government from three senatorial zones in Anambra state and
200 respondents for each local governments.

A total of 1200 respondents will be selected for questionnaire administration in six (6) delineated local government from three senatorial zones in Anambra state and 200 respondents for each local governments. This research work focuses on ascertaining the reason behind people migrating from rural area to urban centres in Nigeria. Emphasis would be on the local government in Anambra state. 2. Local government from each senatorial zone. We have three senatorial zones in Anambra state. Therefore, we selected 1 urban local government and 1 rural local government from each senatorial zone.

\section{Data Presentation and Analysis}

An analysis was run through a statistical package named 'SPSS', using the chi- square test to analyze the hypothesis with the ultimate aim of establishing the reason behind ruralurban migration in Nigeria (proxy by Anambra state, using six Local Government Areas namely; Awka South, Awka North; Nnewi North; Orumba North, Onitsha North and Ayamelum respectively). A total of 1200 questionnaires were distributed to the respondents in each of the six LGA's of the states.

\section{Presentation of Questionnaire Response Data}

The questionnaire distributed was structured as a five point Likert questionnaire; a five-point module was chosen in a bid to achieve symmetry in-between the responses and as well to achieve an equidistant measure between the points. The coding for the responses was done as follows;Strongly Agreed $=5$, Agreed $=4$, Neutral $=3$, Disagreed $=2$, Strongly Disagreed $=1$ Thus, the above coding was done in a regressive manner from 5-1, the further out the response from 5 closing on 1 indicates the more negative the response is, while the closer the response is to 5 , the more positive the response is.

Table 2. Presentation of Questionnaire Response Data.

\begin{tabular}{llllllll}
\hline & Awka South & Awka North & Nnewi North & Orumba North & Onitsha North & Ayamelum & Total \\
\hline VALID & 152 & 149 & 161 & 138 & 157 & 143 & 900 \\
INVALID & 37 & 22 & 23 & 57 & 39 & 39 & 217 \\
NOT RETURNED & 11 & 29 & 16 & 5 & 4 & 18 & 83 \\
TOTAL & 200 & 200 & 200 & 200 & 200 & 200 & 1200 \\
\hline
\end{tabular}

Source: field work 2016

Table 3. Responses to Question No. 1 Section A.

\begin{tabular}{|c|c|c|c|c|c|c|}
\hline \multicolumn{7}{|c|}{ Q1: People migrate from rural - urban area for employment opportunity } \\
\hline & AWKA SOUTH & AWKA NORTH & NNEWI NORTH & ORUMBA NORTH & ONITSHA SOUTH & AYAMELUM \\
\hline SA & 97 & 93 & 86 & 88 & 73 & 64 \\
\hline A & 22 & 30 & 37 & 19 & 49 & 69 \\
\hline $\mathrm{N}$ & 7 & 10 & 8 & 4 & 9 & 3 \\
\hline $\mathrm{D}$ & 15 & 11 & 21 & 7 & 0 & 4 \\
\hline SD & 11 & 2 & 4 & 0 & 4 & 0 \\
\hline TOTAL & 152 & 146 & 156 & 118 & 135 & 140 \\
\hline
\end{tabular}

$\mathrm{S} . \mathrm{A}=\mathrm{STRONGLY}$ AGREED, $\mathrm{A}=\mathrm{AGREED}, \mathrm{N}=$ NEUTRAL, $\mathrm{D}=$ DISAGREED, $\mathrm{S} . \mathrm{D}=\mathrm{STRONGLY}$ DISAGREED 


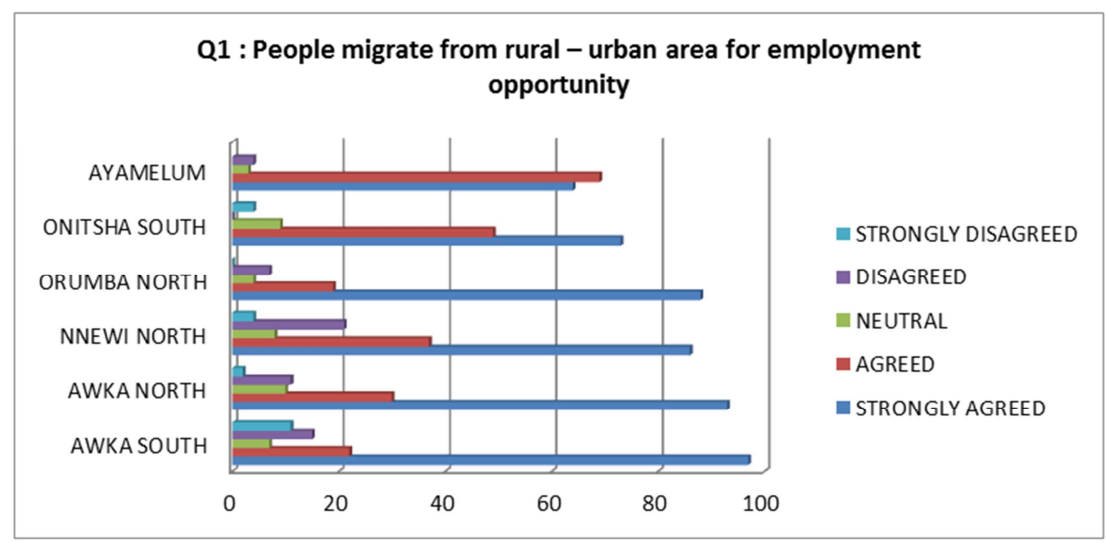

Source: field work 2016

Figure 1. Mode Analysis of Question No.1 Section A.

i. From the above diagram, it can be inferred that the different respondents has a consensus displayed by their response that depicts they strongly agree mostly that rural-urban migration is mostly based on the search for better employment opportunity.

Chi-Square Analysis

The Chi-square test is a test of hypothesis, used to test for the goodness of fit which is applied in comparing the observed and expected frequencies in each category. It is conducted to influence the statistical decision of the analysis and hypothesis under test. The decision rule for acceptance or rejection of the null hypothesis is: If the $\mathrm{X}^{2}$ calculated is greater than $\mathrm{X}^{2}$ tabulated, then the null hypothesis is rejected. For the Chi-square analysis, the five-point Likert questionnaire will be reduced to three-points, where; Strongly Agreed and Agreed $=1$, Disagreed and Strongly Disagreed $=2$, while Neutral $=3$.

Table 4. Chi-Square Test for Hypothesis 1 (Question No. 1).

\begin{tabular}{|c|c|c|c|c|c|c|}
\hline \multicolumn{7}{|l|}{ Test Statistics } \\
\hline & $\begin{array}{l}\text { People Migrate } \\
\text { From Rural- } \\
\text { Urban Areas for } \\
\text { Employment } \\
\text { Opportunity } \\
\text { (Awka South) }\end{array}$ & $\begin{array}{l}\text { People Migrate } \\
\text { from Rural- } \\
\text { urban Areas for } \\
\text { Employment } \\
\text { Opportunity } \\
\text { (Awka North) }\end{array}$ & $\begin{array}{l}\text { People Migrate } \\
\text { from Rural- } \\
\text { Urban Areas for } \\
\text { Employment } \\
\text { Opportunity } \\
\text { (Nnewi North) }\end{array}$ & $\begin{array}{l}\text { People Migrate } \\
\text { from Rural- } \\
\text { urban Areas for } \\
\text { Employment } \\
\text { Opportunity } \\
\text { (Orumba } \\
\text { North) } \\
\end{array}$ & $\begin{array}{l}\text { People Migrate } \\
\text { from Rural- } \\
\text { urban Areas for } \\
\text { Employment } \\
\text { Opportunity } \\
\text { (Onitsha North) }\end{array}$ & $\begin{array}{l}\text { People Migrate } \\
\text { from Rural- } \\
\text { urban Areas for } \\
\text { Employment } \\
\text { Opportunity } \\
\text { (Ayamelum) }\end{array}$ \\
\hline Chi-Square & 208.839 & 253.960 & 263.539 & 230.233 & 257.570 & 201.239 \\
\hline & 2 & 2 & 2 & 2 & 2 & 2 \\
\hline Asymp. Sig. & .005 & .020 & .000 & .009 & .0463 & .001 \\
\hline
\end{tabular}

Source: field work 2016

The hypothesis being evaluated in table 4 is re-stated below;

i. Ho: Employment opportunity has no significant impact on rural-urban migration in Nigeria?

From the above results, using 5\% L.0.S (Level Of Significance) which has a critical value under 3 degree of freedom as 3.84 , hence since $\mathrm{X}^{2}$ calculated $>\mathrm{X}^{2}$ tabulated $(208.8,253.9,263.5,230.2,257.5,201.2>3.84)$, for all local government areas, secondly all p- values are less than 0.05 ; thus, the null hypothesis is rejected and the alternative is accepted.

Table 5. People migrate from rural areas to urban centres.

\begin{tabular}{|c|c|c|c|c|c|c|c|c|}
\hline $\mathbf{S} / \mathbf{n}$ & Question & SA & $\mathbf{A}$ & $\mathbf{N}$ & D & SD & t-value & P -value \\
\hline 1 & For employment opportunity & $\begin{array}{l}886 \\
(73.8 \%)\end{array}$ & $\begin{array}{l}257 \\
(21.4 \%)\end{array}$ & $\begin{array}{l}29 \\
(2.4 \%))\end{array}$ & $\begin{array}{l}0 \\
(0.0 \%)\end{array}$ & $\begin{array}{l}28 \\
(2.3 \%)\end{array}$ & -2.142 & 0.099 \\
\hline 2 & $\begin{array}{l}\text { To have access to infrastructural } \\
\text { amenities }\end{array}$ & $\begin{array}{l}657 \\
(54.8 \%)\end{array}$ & $\begin{array}{l}486 \\
(40.5 \%)\end{array}$ & $\begin{array}{l}29 \\
(2.4 \%)\end{array}$ & $0(0.0 \%)$ & $\begin{array}{l}28 \\
(2.3 \%)\end{array}$ & -2.607 & 0.060 \\
\hline 3 & To acquire wealth & $\begin{array}{l}800 \\
(66.7 \%)\end{array}$ & $\begin{array}{l}363 \\
(30.3 \%)\end{array}$ & $\begin{array}{l}0 \\
(0.0 \%)\end{array}$ & $\begin{array}{l}19 \\
(1.6 \%)\end{array}$ & $\begin{array}{l}18 \\
(1.5 \%)\end{array}$ & -2.313 & 0.082 \\
\hline 4 & To acquire quality education & $\begin{array}{l}685 \\
(57.1 \%)\end{array}$ & $\begin{array}{l}411 \\
(34.3 \%)\end{array}$ & $\begin{array}{l}0 \\
(0.0 \%)\end{array}$ & $\begin{array}{l}87 \\
(7.3 \%)\end{array}$ & $\begin{array}{l}17 \\
(1.4 \%)\end{array}$ & -2.691 & 0.050 \\
\hline 5 & To enjoy a developed area & $\begin{array}{l}300 \\
(25.0 \%)\end{array}$ & $\begin{array}{l}800 \\
(66.7 \%)\end{array}$ & $\begin{array}{l}0 \\
(0.0 \%)\end{array}$ & $\begin{array}{l}83 \\
(6.9 \%)\end{array}$ & $\begin{array}{l}17 \\
(1.4 \%)\end{array}$ & -2.402 & 0.074 \\
\hline
\end{tabular}

Source: field work 2016 


\begin{tabular}{ll}
\hline $\mathbf{S} / \mathbf{n}$ & Question \\
\hline 1 & For employment opportunity \\
2 & To have access to infrastructural amenities \\
3 & To acquire wealth \\
4 & To acquire quality education \\
5 & To enjoy a developed area \\
\hline & \\
\hline Question & SA \\
\hline 1 & $73.80 \%$ \\
3 & $54.80 \%$ \\
4 & $66.70 \%$ \\
5 & $57.10 \%$ \\
\hline
\end{tabular}

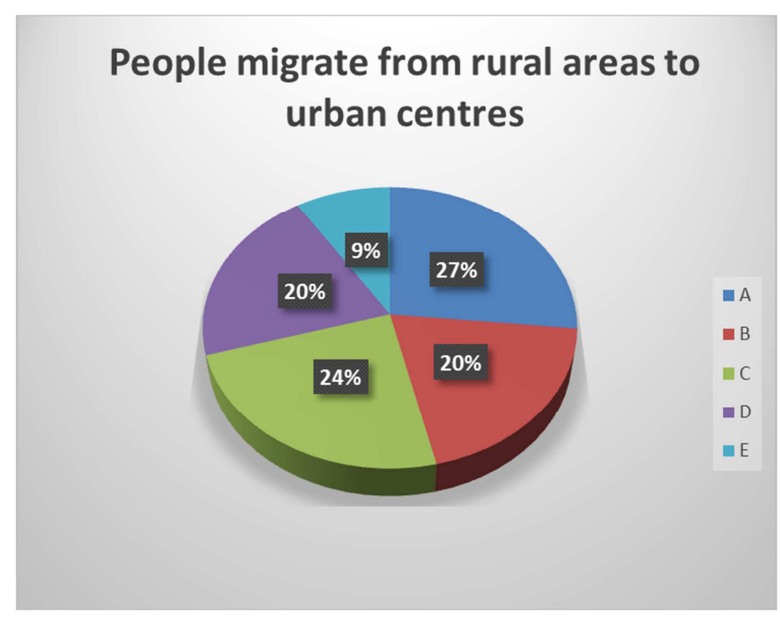

Source: field work 2016

Figure 2. Pie chart.

The results of the pie chart show that the reasons people migrate from rural areas to urban centres is to enjoy the following; employment opportunities with $27 \%$, infrastructural amenities with $20 \%$, acquire wealth with $24 \%$ and quality education with $20 \%$.

\section{Result and Discussion}

In the context of this research, from the analysis conducted through primary data collection, graphical presentations and chi-square tests, the research work has the following findings: people migrate from rural to urban areas in search better employment opportunities, have access to infrastructural amenities, to acquire wealth and acquire quality education. The results of the pie chart show that the reasons people migrate from rural areas to urban centres is to enjoy the following; employment opportunities with $27 \%$, infrastructural amenities with $20 \%$, acquire wealth with $24 \%$ and quality education with $20 \%$. The chi-square results for the first hypothesis showed a high level of significance, thus leading to the conclusion that employment opportunity plays a cogent role in rural-urban migration.

\section{Conclusion}

In the context of this research, from the analysis conducted through primary data collection, graphical presentations and chi-square tests, the research work has the following findings: people migrate from rural to urban areas in search better employment opportunities; rural-urban migration has led to an increase in crime rate in the urban areas; rural-urban migration has negative socio-economic impact as the attention of government is drawn to development of urban areas, thus neglecting the rural areas.

The chi-square results for the hypothesis showed a high level of significance, thus leading to the conclusion that employment opportunity plays a cogent role in rural-urban migration, thus the null hypothesis in this case was rejected. It must be stressed that public policy on agriculture has by and large shown great disaffection towards the small scale farmers; particularly those on the rural areas, as the inputs, credits and other facilities show its bias in favor of the urban bourgeoisie farmers at the expense of the predominant peasant farmers that constitute greater number of the population. The paper therefore recommended that:

(1) The government should embark on rural development such as building of schools, health facilities, recreational centers, good roads etc to reduces the rate at which people migrate to urban centres.

(2) The government should create employment opportunities in the rural areas through massive investment in agricultural sector and establishment of industries in the rural areas to accommodate the unemployed youths.

\section{References}

[1] Ajaero, C. K and Onokala, P. C (2013) The Effects of RuralUrban Migration on Rural Communities of Southeastern Nigeria International Journal of Population Research http://dx.doi.org/10.1155/2013/610193

[2] Abah, N. (2010) Development Administration: A MultiDisciplinary Approach. Enugu: John Jacob Classic Publishers.

[3] Amrevurayire, E. O \& Ojeh, V. N (2016) Consequences Of Rural-Urban Migration On The Source Region of Ughievwen Clan Delta Statenigeria European Journal of Geography Volume 7, Number 3: 42 57, September.

[4] Nweke, A. C. (2019) Rural-Urban Migration in Nigeria, Implication on the Development of the Society: Anambra State as the Focus of the Stud Journal of Public Administration and Governance ISSN 2161-7104 2019, Vol. 9, No. 2 https://doi.org/10.5296/jpag.v9i2.14912

[5] Alhaji A. A \& Lawal A (2017). Urbanization, Cities, and Health: The Challenges to Nigeria - A Review https://www.ncbi.nlm.nih.gov/pmc/articles/PMC5676403/

[6] Ezeani E. O\&Elekwa N. N (2001). Issues in Urbanization and Urban Administration in Nigeria. Enugu: Jamoe Enterprises.

[7] Watts, M. (1983) State, Oil and Agriculture in Nigeria. USA: California University Press.

[8] Ezeah, P. (2005) Rural Sociology and Rural Development with Focus on Nigeria. Enugu: John Jacob Classic Publishers. 
[9] Afolayan, S. O. (1995). Community Mobilization for Rural Development in Bangladesh: Lessons for Nigeria. Ilorin: Agricultural and Rural Management Training Institute, ARMTI.

[10] Ele, C. (2006) Evangelization through Rural Development. Nsukka: Great AP Publishers Ltd.

[11] Nyagba, S. (2009) "Review of Nigeria's Rural Development Policy for sustainable Development" paper presented at Business Round Table at Abuja, 9-11 July.

[12] Gadd, P. (1976) The Ecology of Urbanization and Industrialization, Macmillan, London.

[13] Olabode, E. O; Saidat, D. O \& Oluyemi, E. O (2015) RuralUrban Migration in South Western Nigeria: A menace to National Development Civil and Environmental Research www.iiste.org Vol. 7, No. 5, https://www.researchgate.net
[14] Alarima, C. I. (2018) ACTORS INFLUENCING RURALURBAN MIGRATION OF YOUTHS IN OSUN STATE, NIGERIA Agro-Science Journal of Tropical Agriculture, Food, Environment and Extension Volume 17 Number 3, September https://www.ajol.info/index

[15] Lipton, M. (1977). Why poor people stay poor: a study of urban bias in world development http://hdl.handle.net/1885/114902

[16] Bates, R. H. (1981). Markets and States in Tropical Africa: The Political Basis of Agricultural Policies: (California Series on Social Choice \& Political Economy) https://www.amazon.com/Markets-States-Tropical-AfricaAgricultural/dp/0520244931 